\title{
Pengembangan Lembar Kerja Siswa Menggunakan Pendekatan Saintifik Untuk Meningkatkan Keterampilan Berfikir Kritis Siswa Kelas V Sekolah Dasar
}

\author{
Suryaman \\ Program Studi PGSD Universitas Islam Raden Rahmat Malang \\ suryaman.unira@gmail.com \\ Fitria Ningsih \\ Program Studi PGSD Universitas Islam Raden Rahmat Malang \\ fitrianing133@gmail.com
}

\begin{abstract}
The purpose of this research to produce student worksheets scientific based on the demands of the 2013 curriculum to improve the critical thinking skills of elementary school $V$ students on thematic learning worthy of use in the learning process. This type of research is research and development. The data collection techniques conducted by researchers is a poll and a test. This research findings in the form of learning media is a scientific-based student worksheet. Based on the validation results of the media expert, the percentage of eligibility gained as much as $94 \%$. Results obtained from validation by the material members as much as $95 \%$. The results of the student response poll as much as $97 \%$. Based on the results of the pretests the average critical thinking skill of 35 , in the postest result of an average score of 96.66. While the $N$-gain score increased critical thinking skills of 0.95 with the category high. Thus, it can be concluded that the students' critical thinking skills have increased based on five critical thinking skills.
\end{abstract}

Keyword: Student Worksheets, scientific approaches, critical thinking skills

\section{Pendahuluan}

Pendidikan mempunyai peranan penting untuk menghasilkan peserta didik yang berkualitas. Pendidikan yang bermutu dapat membantu peserta didik berkembang secara dinamis dan mampu berfikir kritis, kreatif, logis dan berinisiatif menanggapi permasalahan dalam kehidupan. Upaya meningkatkan mutu pendidikan sudah dilakukan pemerintah, namun upaya tersebut belum menunjukkan hasil yang optimal kepada siswa, karena rendahnya keterampilan berfikir kritis siswa yang disebabkan oleh ketidaksesuaian proses pembelajaran dengan aturan yang telah ditetapkan. Menurut Wirtha (2016) terdapat siswa yang hanya menghafal konsep dan mencatat apa yang disampaikan guru, dan jarang menggunakan pengetahuan awal dalam pembelajaran sehingga menyebabkan kurangnya keterampilan berfikir kritis siswa.

Kurangnya keterampilan berfikir kritis siswa dapat mempengaruhi tujuan pembelajaran yang akan dicapai. Keterampilan berfikir perlu dimiliki oleh peserta didik dalam proses belajar. Salah satunya adalah keterampilan berfikir kritis (Kemendikbud, 2016). Menurut Ennis (2011) menambahkan bahwa berfikir kritis 
adalah pemikiran yang masuk akal dan berfokus untuk memutuskan apa yang dipercaya dan apa yang akan dilakukan Peserta didik yang dibekali dengan keterampilan berfikir kritis dapat menganalisis secara cermat dan teliti tehadap suatu masalah yang dihadapi, serta mengidentifikasi dan mengkaji informasi yang didapat guna memecahkan sebuah permasalahan. Pendapat tersebut diperkuat oleh Azizah, dkk (2018) bahwa berfikir kritis adalah berfikir yang reflektif secara mendalam dalam mengambil sebuah keputusan dan pemecahan masalah untuk menganalisis situasi, mengevaluasi argumen, serta menarik kesimpulan dengan tepat.

Menurut Baiq (2017) keterampilan berfikir kritis siswa dapat dikembangkan melalui suatu pendekatan yang dapat memaksimalkan tujuan berfikir kritis itu sendiri yaitu untuk mencapai pemahaman yang mendalam serta mengkaji suatu persoalan secara terarah dan jelas, sehingga kebenaran dapat dipertanggungjawabkan. Oleh sebab itu pendekatan saintifik mampu memberikan solusi terhadap permasalahan dalam pembelajaran. Pendekatan saintifik merupakan suatu pendekatan atau suatu metode pembelajaran yang digunakan oleh pendidik dan peserta didik pada jenjang pendidikan dasar dalam proses pembelajaran terdiri dari kegiatan mengamati, menanya, menalar, mencoba dan mengkomunikasikan. Menurut (Daryanto, 2014) bahwa pembelajaran dengan menggunakan pendekatan saintifik adalah proses pembelajaran yang dirancang sedemikian rupa agar peserta didik mampu mengkonstruksi pengetahuannya sendiri melalui tahapan mengamati, merumuskan masalah, merumuskan hipotesis, mengumpulkan data dengan berbagai teknik, menganalisis data, menarik kesimpulan, mengkomunikasikan konsep, hukum atau prinsip yang ditemukan.

Pembelajaran menggunakan pendekatan saintifik dapat diimplementasikan dengan berbagai perangkat pembelajaran. Salah satu perangkat pembelajaran yang dapat digunakan adalah Lembar Kerja Siswa. Lembar kerja siswa adalah lembaranlembaran yang berisi pedoman bagi peserta didik dalam melakukan kegiatan terprogram seperti pengamatan, percobaan, dan pengajuan pertanyaan sehingga dapat dilakukan secara aktif (Trianto, 2011). Keberadaan LKS dalam kegiatan pembelajaran menjadi sangat penting. Sejalan dengan diberlakukannya kurikulum 2013, maka LKS yang digunakan harus didesain menggunakan pendekatan saintifik. Hal ini dibenarkan oleh Sri Estu, dkk (2016) bahwa Lembar Kerja Siswa berbasis saintifik merupakan panduan kegiatan yang menuntun siswa untuk menemukan suatu konsep secara ilmiah. Hal ini sesuai dengan penerapan pendekatan saintifik sebagaimana ditetapkan kurikulum 2013.

Berdasarkan hasil observasi dengan siswa siswi kelas 5 SD Modern Al-Rifa'ie pada tanggal 20 November 2019 memperlihatkan bahwa guru dan siswa menggunakan LKS praktis dalam proses pembelajaran. LKS praktis ini berisi materi singkat, kegiatan pembelajaran yang belum berpusat pada siswa, serta soal-soal yang hanya mencakup pada kemampuan mengingat dan memahami. Hal tersebut menyebabkan peserta didik kurang dirangsang untuk meningkatkan kemampuan berpikir kritis. Penggunaan LKS praktis dipilih guru karena kurangnya keterampilan guru dalam membuat dan menyusun LKS berbasis saintifik. Padahal LKS merupakan suatu media ajar serta bukti yang nyata dari pekerjaan peserta didik pada saat proses pembelajaran.

Berdasarkan permasalahan diatas maka dapat disimpulan bahwa guru masih mengalami kesulitan mengenai penyusunan dan pengembangan LKS menggunakan pendekatan saintifik. Guru juga masih membutuhkan contoh LKS yang baik dan menarik sehingga nantinya akan berpengaruh terhadap keerampilan berpikir kritis siswa. Atas dasar tersebut peneliti mencoba untuk mengembangkan Lembar Kerja 
Siswa Menggunakan Pendekatan Saintifik Untuk Meningkatkan Keterampilan Berpikir Kritis Siswa Kelas V Sekolah Dasar

\section{Metode}

Penelitian ini dilakukan di SD Modern Al- Rifa'ie 2 Desa Ketawang Kecamatan Gondanglegi Kabupaten Malang. Penelitian dan pengembangan ini bertujuan untuk menghasilkan perangkat belajar yang dapat menunjang proses pembelajaran di kelas dengan mengembangkan suatu produk yang berupa Lembar Kerja Siswa (LKS). LKS dikembangkan menggunakan pendekatan saintifik untuk meningkatkan keterampilan berfikir kritis siswa kelas V Sekolah Dasar. Pada penelitian ini, peneliti akan mengunakan metode penelitian dan pengembangan atau Research and Development dengan menggunakan model Borg and Gall dalam penelitiannya. Metode penelitian yang digunakan bertujuan menghasilkan produk tertentu, dan menguji keefektifan produk yang telah dikembangkan (Sugiono, 2011).

Peneliti dalam hal ini melakukan pembatasan langkah-langkan pengembangan yang diadaptasi dari pengembangan Borg and Gall. Borg and Gall menyatakan bahwa sangat dimungkinkan bagi peneliti untuk membatasi penelitian skala kecil, termasuk membatasi langkah-langkah penelitian. Penerapan langkah-langkah pengembangannya disesuaikan dengan kebutuhan peneliti. Mengingat keterbatasan waktu dan dana yang dimiiki oleh peneliti. Maka langkah-langkah yang dilakukan peneliti adalah : 1) Potensi dan Masalah, 2) Analisis Kebutuhan, 3) Pengembangan Produk, 4) Validasi Ahli Media dan Ahli Materi, 5) Revisi Produk, 6) Uji Coba Kelompok Terbatas, 7) Revisi Final.

Teknik analisis data pada penelitian ini antara lain data kualitatif yang merupakan teknik untuk menganalisis dan menjelaskan data-data yang dinyatakan dengan katakata atau berbentuk uraian dalam lembar observasi, pedoman wawancara, angket penilaian ahli media, serta angket penilaian ahli materi. Sedangkan data kuantitatif digunakan untuk menganalisis data-data berbentuk angka yang diperoleh dari hasil validasi ahli materi, dan validasi ahli media dan angket respon siswa. sedangkan untuk analisis $N$-gain keterampilan berfikir kritis siswa dari hasil pretest dan postest siswa.

\section{Hasil dan Pembahasan}

Lembar Kerja Siswa (LKS) berbasis saintifik dinyatakan valid apabila skor dari validator atau ahli berada dalam kategori sangat layak serta mendapat respon tinggi dari peserta didik. Hasil validasi ahli media mencakup ukuran LKS, desain cover LKS, dan desain isi LKS. Validasi ahli materi mencakup kesesuaian materi dengan Kpmpetensi Inti dan Kompetensi Dasar, kemutakhiran materi, ketercapaian materi, bahasa, kegiatan saintifik, dan evaluasi. Rekapitulasi hasil validasi ahli media dapat dilihat pada tabel 1 , sedangkan rekapitulasi hasil validasi ahli materi dapat dilihat pada tabel 2 .

Tabel 1. Rekapitulasi Hasil Validasi Ahli Media

\begin{tabular}{clc}
\hline No. & \multicolumn{1}{c}{ Aspek Yang di Nilai } & Skor \\
\hline 1. & Ukuran LKS & 8 \\
2. & Desain Sampul LKS & 18 \\
3. & Desain Isi LKS & 49 \\
Jumlah & & 75 \\
Persentase & & $94 \%$ \\
Kategori & & Sangat Layak \\
\hline
\end{tabular}


Tabel 2. Rekapitulasi Hasil Validasi Ahli Materi

\begin{tabular}{clc}
\hline No. & \multicolumn{1}{c}{ Aspek Yang di Nilai } & Skor \\
\hline 1. & Kesesuaian Materi dengan KI KD & 4 \\
2. & Kemutahiran Materi & 7 \\
3. & Ketercapain Materi & 3 \\
4. & Bahasa & 8 \\
5. & Karakteristik Pendekatan Saintifik & 35 \\
6. & Evaluasi & 4 \\
Jumlah & & 61 \\
Persentase & & $95 \%$ \\
Kategori & & Sangat Layak \\
\hline
\end{tabular}

Berdasarkan data pada tabel di atas, menunjukkan bahwa validasi ahli media dan ahli materi berupa Lembar Kerja Siswa menggunakan pendekatan saintifik ini telah memenuhi kriteria penilaian butir instrumen penilaian ahli media dan ahli materi. LKS yang dikembangkan telah didesain dengan tampilan yang menarik sesuai dengan tahapan perkembangan peserta didik, desain isi telah disesuaikan dengan pembelajaran saintifik sesuai kurikulum 2013. LKS saintifik ini menggunakan tema yang telah disesuaikan dengan kalender akademik, program tahunan dan program semester. Materi yang disusun sesuai Kompetensi Inti dan Kompetensi Dasar serta indikator ketercapaian. LKS juga disusun menggunakan bahasa yang mudah dipahami siswa, tidak menimbulkan makna ganda dan sesuai tingkat perkembangan siswa. kegiatan pada LKS ini sudah sesuai dengan kegiatan pembelajaran saintifik yang meliputi mengamati, menanya, mencoba, menalar, dan mengkmunikasikan.

Setelah tahapan validasi dari ahli media dan ahli materi maka selanjutnya adalah uji coba produk. Uji coba produk dilakukan pada kelompok terbatas yaitu 6 siswa siswi kelas 5 Sekolah Dasar Data dari hasil uji coba kelompok terbatas diperoleh dari nilai hasil tes tulis berupa pretest dan postes. Soal pretest dan postes berisi 5 butir soal uraian yang bertujuan untuk mengetahui keterampilan berpikir kritis siswa. Hasil tes keterampilan berfikir kritis yang dicapai oleh siswa siswi pada uji coba kelompok terbatas ditunjukkan pada tabel di bawah ini:

Tabel 3. Hasil Pretest dan Postets Kemampuan Berfikir Kritis Siswa

\begin{tabular}{c|c|c|c}
\hline No. & Nilai Siswa & Skor Pretest & Skor Postest \\
\hline 1. & Nilai Terendah & 15 & 90 \\
2. & Nilai Tertinggi & 75 & 100 \\
Rata-rata nilai tes & 35 & 96,66 \\
N-Gain & & 0,95 & \\
\hline
\end{tabular}

Pada penelitian ini aspek keterampilan berfikir kritis yang ditinjau meliputi: 1) memberikan penjelasan sederhana (menjawab pertanyaan yang membutuhkan penjelasan), 2) membangun keterampilan dasar (mengobservasi dan mempertimbangkan hasil observasi), 3) membuat kesimpulan (melakukan deduksi dan menilai hasil deduksi), 4) memberikan penjelasan lebih lanjut (mendefinisikan istilah dan mempertimbangkan definisi menggunakan kriteria yang tepat), 5) membuat perkiraan dan integrasi dengan orang lain (berintegrasi dengan oranglain). Data hasil tes keterampilan berfikir kritis pada masing-masing aspek dapat dilihat pada gambar 1 sebagai berikut. 


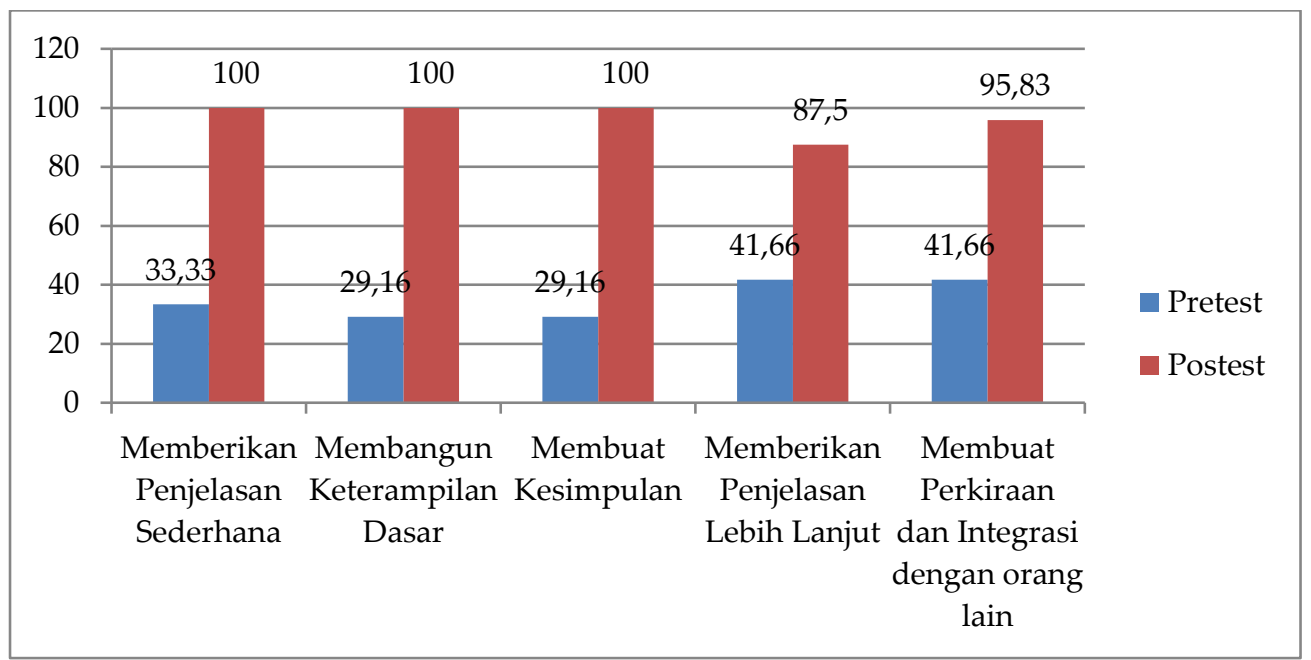

Gambar 1. Diagram Peningkatan Keterampilan Berfikir Kritis Pada Masing-Masing Indikator

Skor rata-rata perolehan hasil tes keterampilan berfikir kritis siswa dari ke lima aspek pada tabel di atas menunjukkan bahwa total rata-rata skor $N$-Gain adalah 0,95 dengan kategori Tinggi. Tingginya keterampilan berfikir kritis siswa yang telah dicapai pada setiap aspek keterampilan berfikir kritis berdasarkan soal yang diberikan akan dijelaskan sebagai berikut.

1) Memberikan Penjelasan Sederhana

Pada aspek ini peneliti menganalisis indikator keterampilan berfikir kritis siswa yaitu keterampilan memberikan penjelasan atau kesimpulan. Kegiatan yang dilakukan oleh guru yaitu siswa dilatih untuk membuat dan menentukan hasil pertimbangan berdasarkan latar belakang atau penerapan fakta (Yonata, 2016). Soal yang diberikan pada asepek ini adalah dengan meminta siswa menjelasakan pengertian dari zat campuran dan menyebutkan contoh dari zat campuran. Alur berfikir kritis siswa pada aspek ini sudah sangat baik. Dari hasil tes siswa pada aspek ini menunjukkan bahwa siswa mampu menjelaskan pertanyaan yang membutuhkan jawaban secara tepat dengan persentase jawaban siswa pada pretest $33,33 \%$ dan postest $100 \%$.

2) Membangun Keterampilan Dasar

Pada aspek ini peneliti menganalisis indikator keterampilan berfikir kritis siswa yaitu mengobservasi dan mempertimbangkan hasil observasi. Berfikir kritis mengarahkan siswa untuk membangun keterampilan dasar (bassic support) meliputi: mempertimbangkan kredibilitas sumber dan melakukan pertimbangan observasi (Ennis R. H., 2011). Soal yang diberikan pada asepek ini adalah dengan meminta siswa mengobservasi gula jika dicampur dengan air dan bubuk kopi jika dicampur dengan air menghasilkan suatu zat campuran. Alur berfikir kritis siswa pada aspek ini sudah sangat baik. Dari hasil jawaban pretest dan postest siswa pada aspek ini menunjukkan bahwa siswa mampu menjelaskan hasil observasi secara tepat dengan persentase skor pretest $29,16 \%$ dan skor postest $100 \%$.

3) Membuat Kesimpulan

Pada aspek ini peneliti menganalisis indikator keterampilan berfikir kritis siswa yaitu melakukan deduksi dan menilai hasil deduksi. Penalaran deduktif merujuk pada kesimpulan dari umum ke khusus sedangkan keterampilan induktif merujuk dari khusus ke umum (Prihatiningsih, 2016) Soal yang 
diberikan pada asepek ini adalah dengan meminta siswa menentukan komponen penyusun yang termasuk pada benda tercampur sempurna dan benda yang tidak tercampur sempurna selanjutnya siswa memberikan hasil berupa kesimpulan. Alur berfikir kritis siswa pada aspek ini sudah sangat baik. Dari hasil jawaban pretest dan postest siswa pada aspek ini menunjukkan bahwa siswa mampu menentukan komponen penyusun yang termasuk tercampur sempurna dan tidak tercampur sempurna serta dapat memberi kesimpulan dengan persentase skor pretest $29,16 \%$ dan skor postest $100 \%$.

4) Membuat Penjelasan Lebih Lanjut

Pada aspek ini peneliti menganalisis indikator keterampilan berfikir kritis siswa yaitu mendefinisikan istilah, dan mempertimbangkan definisi menggunakan kriteria yang tepat. Soal yang diberikan pada asepek ini adalah dengan meminta menjelaskan perbedaan antara tangga nada berdiatonis minor dan tangga nada berdiatonis mayor. Alur berfikir kritis siswa pada aspek ini sudah sangat baik. Dari hasil jawaban pretest dan postest siswa pada aspek ini menunjukkan bahwa siswa mampu menjelaskan perbedaan suatu definisi secara tepat dengan persentase skor pretest $41,66 \%$ dan skor postest $87,5 \%$.

5) Membuat Perkiraan Dan Integrasi

Pada aspek ini peneliti menganalisis indikator keterampilan berfikir kritis siswa yaitu berintegrasi dengan orang lain. Soal yang diberikan pada asepek ini adalah dengan meminta siswa merumuskan pembuatan iklan dengan baik dan benar sesuai dengan unsur-unsur iklan untuk membuktikan sebuah pernyataan yang disarankan diterima atau tidak. Alur berfikir kritis siswa pada aspek ini sudah sangat baik. Dari hasil jawaban pretest dan postest siswa pada aspek ini menunjukkan bahwa siswa mampu berintegrasi serta merumuskan sebuah iklan dengan persentase skor pretest $41,66 \%$ dan skor postest $95,83 \%$.

Setelah melakukan uji coba terbatas, peneliti memberikan angket respon siswa untuk mengetahui apakah media yang digunakan memberikan peningkatan terhadap keterampilan berfikir kritis siswa. Angket respon siswa diberikan kepada 6 siswa kelas V sekolah dasar. Angket respon ini berisi 17 soal pernyataan yang harus dijawab, dengan pilihan jawaban sangat setuju (4), setuju (3), tidak setuju (2) dan sangat tidak setuju (1). Hasil angket respon siswa dapat dilihat pada tabel di bawah ini.

Tabel 1.3 Rekapitulasi Hasil Angket Respon Siswa Terhadap LKS

\begin{tabular}{|c|c|c|c|c|c|c|c|c|c|c|c|c|c|c|c|c|c|c|c|}
\hline \multirow[b]{2}{*}{$\begin{array}{l}\mathbf{N} \\
\mathbf{o}\end{array}$} & \multirow{2}{*}{$\begin{array}{l}\text { Nama } \\
\text { Siswa }\end{array}$} & \multicolumn{17}{|c|}{ Nomor Soal } & \multirow[b]{2}{*}{$\underset{\mathbf{h}}{\mathbf{J m l}}$} \\
\hline & & 1 & 2 & 3 & 4 & 5 & 6 & 7 & 8 & 9 & $\begin{array}{l}1 \\
0\end{array}$ & $\begin{array}{l}1 \\
1\end{array}$ & $\begin{array}{l}1 \\
2\end{array}$ & $\begin{array}{l}1 \\
3\end{array}$ & $\begin{array}{l}1 \\
4\end{array}$ & $\begin{array}{l}1 \\
5\end{array}$ & $\begin{array}{l}1 \\
6\end{array}$ & $\begin{array}{l}1 \\
7\end{array}$ & \\
\hline 1 & EMM & 4 & 4 & 3 & 3 & 4 & 4 & 4 & 4 & 3 & 4 & 4 & 4 & 4 & 4 & 4 & 4 & 4 & 65 \\
\hline 2 & FLI & 4 & 4 & 4 & 4 & 4 & 4 & 4 & 4 & 4 & 4 & 4 & 4 & 4 & 4 & 4 & 4 & 4 & 68 \\
\hline 3 & NAA & 4 & 4 & 4 & 4 & 4 & 4 & 4 & 4 & 4 & 4 & 4 & 4 & 4 & 4 & 4 & 4 & 4 & 68 \\
\hline 4 & $\begin{array}{l}\text { AAG } \\
\text { M }\end{array}$ & 4 & 4 & 4 & 4 & 4 & 4 & 4 & 4 & 4 & 4 & 4 & 4 & 4 & 4 & 4 & 4 & 4 & 68 \\
\hline 5 & $\mathrm{MD}$ & 4 & 4 & 4 & 4 & 4 & 4 & 4 & 4 & 4 & 4 & 4 & 4 & 4 & 4 & 4 & 4 & 4 & 68 \\
\hline 6 & SNW & 3 & 3 & 4 & 4 & 3 & 4 & 3 & 4 & 3 & 4 & 3 & 4 & 4 & 3 & 4 & 4 & 4 & 61 \\
\hline \multicolumn{19}{|c|}{$\begin{array}{c}\text { Jumlah } \\
\text { Rata-Rata } \\
\text { Persentase }\end{array}$} & $\begin{array}{l}398 \\
408 \\
97 \%\end{array}$ \\
\hline
\end{tabular}


Berdasarkan Hasil dari respon siswa yang diperoleh melalui penyebaran angket terhadap 6 siswa kelas V Sekolah Dasar. Angket respon siswa terdapat 17 butir pernyataan dengan menggunakan skala 4 yaitu dengan kategori sangat setuju (4), setuju (3), tidak setuju (2) dan sangat setuju (1). Diperoleh hasil skor 398 dengan persentase $97 \%$. Maka dapat disimpulkan bahwa 97\% LKS berbasis saintifik ini sangat baik digunakan dalam proses pembelajaran untuk meningkatkan kemampuan berpikir kritis siswa

\section{Simpulan}

1. LKS menggunakan pendekatan saintifik untuk meningkatkan keterampilan berfikir kritis siswa kelas V Sekolah Dasar telah diujikan kepada ahli media dan ahli materi Persentase kelayakan yang dihasilkan dari validasi ahli media adalah $94 \%$ dan dari ahli materi sebanyak $95 \%$ sedangkan dari angket respon siswa sebanyak $97 \%$.

2. Pada pelaksanaan uji kelompok terbatas LKS menggunakan pendekatan saintifik untuk meningkatkan keterampilan berfikir kritis siswa kelas V Sekolah Dasar dengan melihat hasil perolehan pretest dan postest keterampilan berfikir kritis siswa. Berdasarkan hasil pretest skor rata-rata keterampilan berfikir kritis sebesar 35, pada hasil postest perolehan skor rata-rata sebanyak 96,66. Sedangkan skor $N$-gain peningkatan keterampilan berfikir kritis sebesar 0,95 dengan kategori "Tinggi".

\section{Referensi}

Daryanto, (2014). Pendekatan Pembelajaran Saintifik Kurikulum 2013. Yogyakarta: Gava Media

Ennis, R. H. (2011). The Nature Of Critical Thinking : An Outline Of Critical Thinking Dispositions and Abilitesi. Chicago: Univercity Of Illinois.

Estu, Sri Winahyu., Kartini, H., Bintarik, L. (2016). Pengembangan LKS Berbasis Saintifik Untuk Meningkatkan Karakter Ilmiah Siswa SD. Jurnal Pendidikan, 25 (1), 74-81.

Kemendikbud. (2016). Peraturan Mentri Pendidikan dan Kebudayaan Republik Indonesia Nomor 21. Jakarta: Kemendikbud.

Mira, Azizah., Sulianto, J., Cintang, Nyai. (2018). Analisis Keterampilan Berfikir Kritis Siswa Sekolah Dasar Pada Pembelajaran Matematika Kurikulum 2013. Jurnal Penelitian Pendidikan, 35 (1), 61-69.

Sugiono. (2011). Metode Penelitian Kuantitatif, Kualitatif dan R\&D. Bandung : CV. Alfabeta.

Sukoyanti, Baiq A., \& Sufianti, Ika. (2017). Pengaruh Pendekatan Saintifik Terhadap Keterampilan Berfikir Kritis Siswa. Jurnal Pendidikan, 3 (2), 3640.

Trianto. (2011). Desain Pengembangan Pembelajaran Tematik Bagi Anak Usia Dini/TK/RA \& Anak Usia Kelas Awal SD/MI. Jakarta. Kencana

Wirtha, I Made \& Rapi, Ni Ketut (2016). Pengaruh Model Pembelajaran dan Penalaran Formal Terhadap Konsep Fisika dan Sikap Ilmiah Siswa. Jurnal Penelitian dan Pengembangan Pendidikan, 1(2), 15-29.

Andriana, V. S. \& Yonata, B. (2016). Keterampilan Berpikir Siswa dalam Memberikan Penjelasan Sederhana dan Menyimpulkan Pada Materi Laju Reaksi Kelas XI SMAN 1 Pamekasan (Students'critical Thinking Skills'to Give Simple Explanation And Conclude On Reaction Rates Material In Class Of Xi Sman 1 Pamekasan). Unesa Journal of Chemical Education, 5(2). 252256.

Zubaidah, Siti. Prihatiningsih. Sentot Kusairi. 2016. Kemampuan Berfikir Kritis Siswa SMP Pada Materi Klarifikasi Makhluk Hidup. Semnas Pendidikan IPA Pascasarjana Universitas Negri Malang. 1, 1058. 